\title{
The synthesis of angular hetarenochromones based on 7-hydroxy-8-carbonylchromones
}

\author{
Tetyana Shokol*, Oleg Lozinski, Natalia Gorbulenko, Volodymyr Khilya \\ Department of Chemistry, Taras Shevchenko National University of Kyiv, Volodymyrska Street, \\ 64/13, Kyiv 01601, Ukraine \\ contacting e-mailshokol_tv@univ.kiev.ua
}

Keywords: 8-formyl/acetyl/benzoyl-7-hydroxychromones, annulation, furo[2,3-h]chromones, pyrano[2,3-f]chromones, isoxazolo[7,8-d]chromones, pyrano[2,3-e]indazol-4-(7H)-one, pyrano[3,2-h]isoquinolin-4-one, hexahydrochromeno[7,8e][1,4]diazepin-4-one.

The present review highlights advanced strategies to the synthesis of the chromones annulated with $O$ - and $N$-containing heterocycles at $\mathrm{C}(7)-\mathrm{C}(8)$ bond. Due to the prevalence of such motives in different kinds of natural flavonoids and some alkaloids, fused chromones have attracted a great deal of attention so far. On the other hand a wide range of biological activities is displayed by the compounds of this type both among naturally occurring flavonoids and their synthetic analogues. 8Carbonyl-7-hydroxychromones proved to be versatile synthones for the synthesis of angular hetarenochromones via approach of annulation of a heterocycle to the chromone core. It also addresses the question of the biological activity of naturally occurring and fused synthetic hetarenochromones.

\section{Introduction}

The chromone system is the core fragment of a group of natural flavonoids which are ubiquitous in nature and possess a wide spectrum of biological activity [1]. Chromones are worth studying in view of a wide scope of their transformations employed in organic synthesis and are reported to be a privileged scaffold in drug discovery [2]. Fused chromones have attracted a great deal of attention owing to a prevalence of such motives in different kinds of natural flavonoids and some alkaloids. Naturally occuring fused flavonoids are rather common to contain a pyran or furan ring annulated with chromene-4-one core. Natural furo[2,3$h]$ chromones and pyrano[2,3-f]chromones are known to possess antiviral, antimicrobial, insecticidal, fungicidal and psychotropic activity [3]. Some synthetic analogs of natural furo[2,3- $h]$ chromones and pyrano[2,3- 
$f$ ]chromones, containing instead of a furan or pyran ring, azole or azine cycle, are much more active, and in some cases, change the pharmacological profile of drugs [4].

Two approaches to the synthesis of chromones annulated with heterocycles at $\mathrm{C}(7)-\mathrm{C}(8)$ bond such as annulation of heterocycle to the chromone core and annulation of $\gamma$-pyrone ring to benzohetarene core have been highlighted in the literature [3].

The introduction of the carbonyl group ortho to the hydroxyl group in 7hydroxychromones promotes the annulation

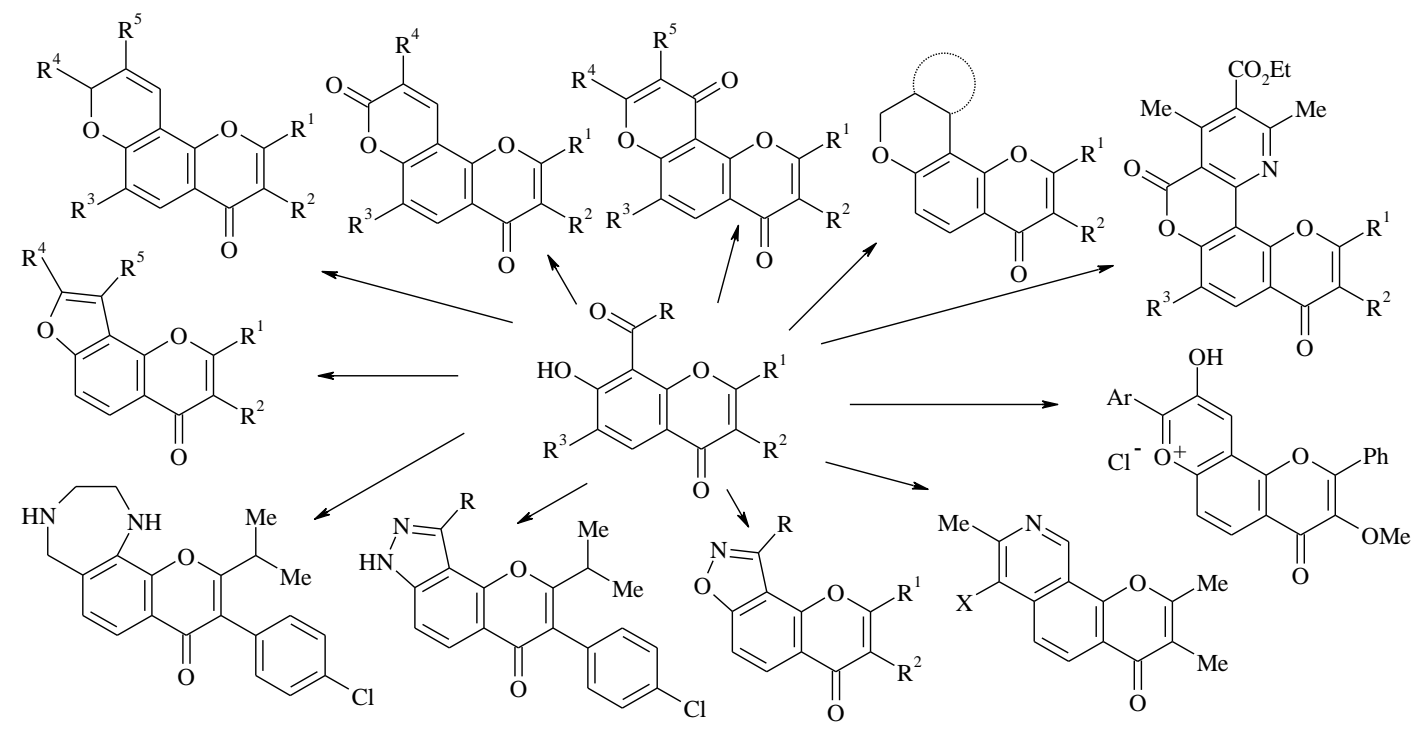

Scheme 1. Hetarenochromones based on 8-carbonyl-7-hydroxychromones

\section{Synthesis of 8-formyl-, acetyl- and benzoyl-7-hydroxychromones}

8-Formyl-, acetyl- and benzoyl-7hydroxychromones, the convenient building blocks for annulation reactions, can be obtained by a concise and effective protocols, reaction at $\mathrm{C}(7)-\mathrm{C}(8)$ bond of chromone cycle. This fact allows consideration 8carbonyl-7-hydroxychromones as versatile synthones for the synthesis of angular hetarenochromones via the first approach.

The present review is focused on the syntheses of furo[2,3- $h$ ]chromones, pyrano[2,3-f]chromones and their elaborated fused derivatives, as well as their $\mathrm{N}$ containing analogues, starting from the 7hydroxy-8-formyl/acetyl/benzoyl-chromones and shows the current status of researches to date (Scheme 1). 
hydroxychromones (1) easily undergo condensation with hexamethylenetetramine (HMTA) in glacial acetic acid solution and on subsequent hydrolysis with hydrochloric acid give comparatively good yields of 8-formyl derivatives (Scheme 2). For the first time this method was applied to 7-hydroxychromones and flavones in 1939 [5], and it remains the main method of synthesis for 8-formyl-7hydroxychromones (2) up to date [6]. Thus, in 2015 a series of novel isoflavonoids, representing structural modifications of daidzein, an active ingredient of traditional Chinese medicine was synthesized and evaluated for its anti-influenza activity, in vitro, against H1N1 Tamiflu-resistant (H1N1 TR) virus in the MDCK cell line. Among them, 8-formyl-7-hydroxyisoflavones were most promising and demonstrated better activities and selectivities comparable to the reference ribarivin, a nucleoside antiviral agent. 3-(4-Bromophenyl)-8-formyl-7- inhibitory activity (EC50, 29.0 $\mu \mathrm{M}$ ) and selectivity index (SI>10.3). Analysis of the structure-activity relationships (SAR) indicated that the presence of both the Bromine in 3-aryl substituent and appropriate $\mathrm{CHO}$ and $\mathrm{OH}$ groups in benzene core of chromone system might be critical for the activity and selectivity against H1N1 TR influenza viruses [7]. Having successfully accomplished the Duff reaction to 7hydroxyisoflavones [8], we then employed the protocol to their 3-phenoxy- [9] and 3hetaryl analogues, such as (3-(4-phenyl-4H1,2,4-triazol-3-yl)- and 2-methyl-5methoxycarbonylfuran-3-yl derivatives $[10$, 11]. 3-(4-Methylthiazol-2-yl)- and 3-(1phenylpyrazol-4-yl) derivatives were synthesized via the Duff reaction in modified conditions upon stirring 3-hetaryl-7hydroxychromones and HMTA in trifluoroacetic acid in a closed vial under argon at $110^{\circ} \mathrm{C}$ for $40 \mathrm{~min}$ [12]. hydroxychromone displayed the best

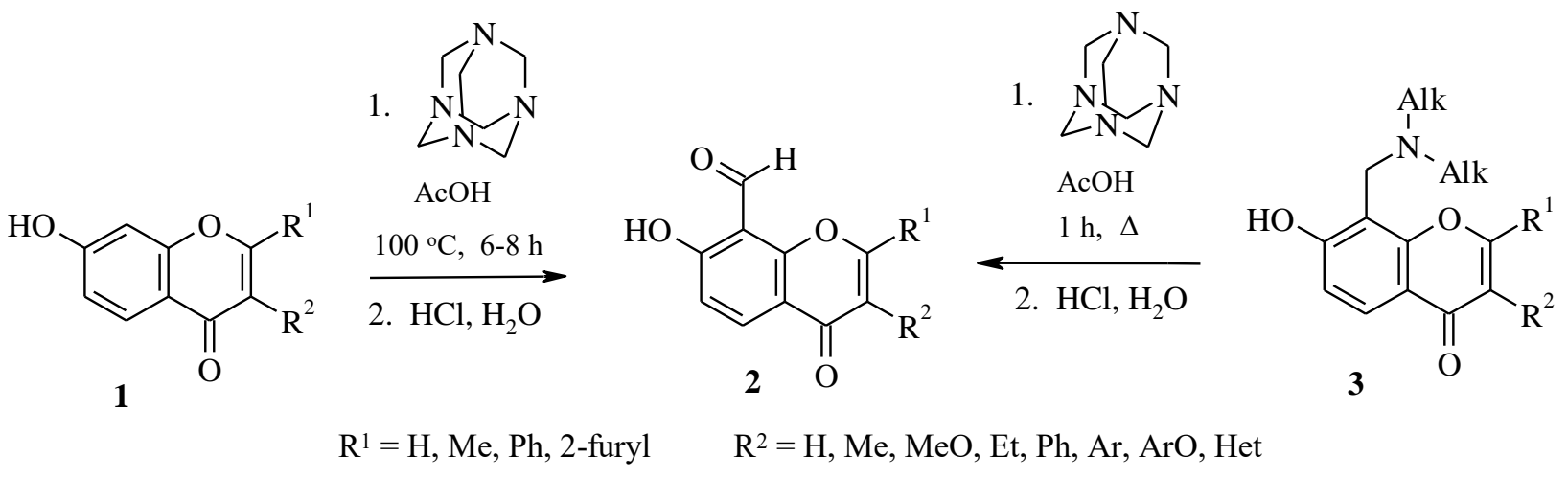

Scheme 2. The synthesis of 8-formyl-7-hydroxychromones 
Under the Duff conditions the Mannich bases can also serve as starting materials in the 8-formyl-7hydroxychromones' synthesis [13]. Heating of 8-dialkylamino-7-hydroxychromones with HMTA in acetic acid during $1 \mathrm{~h}$, followed by acid hydrolysis proved to be a convenient method for synthesis of 8-formyl7-hydroxyisoflavones and their 3-hetaryl analogues (2) [10, 14] (Scheme 2).

The approach relied upon acylation of 7-hydroxychromones 1 with acetic anhydride,

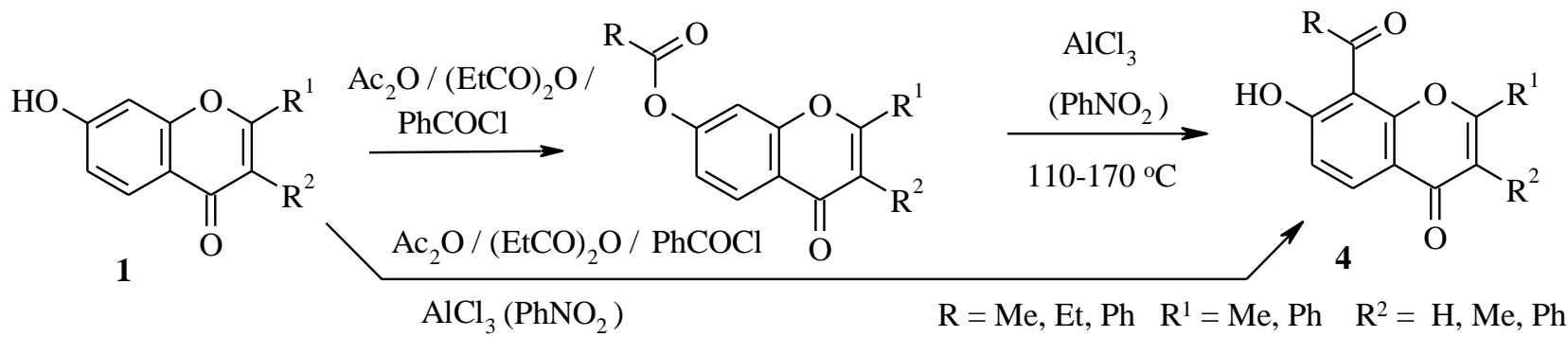

Scheme 3. The synthesis of 8-acyl- and 8-benzoyl-7-hydroxychromones propionic anhydride or benzoyl chloride followed by the Friss rearrangement enabled to obtain 8-acyl-7-hydroxychromones (4) [1517] (Scheme 3). Similarly the Friedel-Crafts acylation, propyonilation and benzoylation of 7-hydroxychromones $\mathbf{1}$ in $\mathrm{AlCl}_{3}$ led to the corresponding 8-acetyl-, 8-propionyl and 8benzoylchromones 4 in 60-70\% yields [17]. When the above reaction was carried out in nitrobenzene as a solvent, lower yields were obtained [17].
8-Formyl-, acetyl- and benzoyl-7hydroxychromones have been successfully used for annulation of 5, 6 and 7 membered heterocycles to the chromone core.

\section{Furo[2,3-h]chromones}

Chromones annulated with the furan ring are an abundant subclass of flavonoids, which are widely distributed in nature. Naturally abundant furo[2,3-h]flavones, such as lancheolatin B (5), pongoglabol (6), pongaglabol methyl ether (7), pongaglabrone (8) and karanjin (9) which are the major constituents of the Pongamia genus are known to possess antibacterial, antifungal and cytotoxic activity [18, 19] (Figure 1). Karanjin is used as bioinsecticide and biopesticide [19]. The wide range of biological properties of natural furo[2,3$h$ chromones has stimulated interest in the synthesis of such system derivatives.

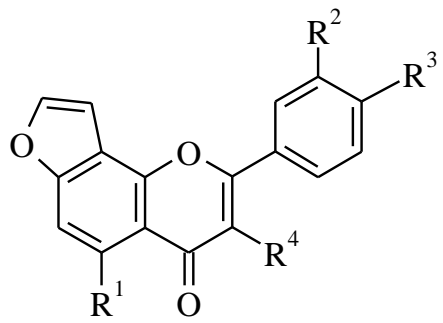

5. $\mathrm{R}^{1}=\mathrm{R}^{2}=\mathrm{R}^{3}=\mathrm{R}^{4}=\mathrm{H}$ lancheolatin $\mathrm{B}$

6. $\mathrm{R}^{1}=\mathrm{OH}, \mathrm{R}^{2}=\mathrm{R}^{3}=\mathrm{R}^{4}=\mathrm{H}$ pongaglabol

7. $\mathrm{R}^{1}=\mathrm{OMe}, \mathrm{R}^{2}=\mathrm{R}^{3}=\mathrm{R}^{4}=\mathrm{H}$ pongaglabol methyl ether

8. $\mathrm{R}^{1}=\mathrm{R}^{4}=\mathrm{H}, \mathrm{R}^{2}+\mathrm{R}^{3}=-\mathrm{O}-\mathrm{CH}^{2}-\mathrm{O}-$ pongaglabrone

9. $\mathrm{R}^{1}=\mathrm{R}^{2}=\mathrm{R}^{3}=\mathrm{H}, \mathrm{R}^{4}=\mathrm{MeO}$ karanjin

Figure 1. Natural furo[2,3- $h]$ flavones 
A number of furo[2,3- phase transfer catalyst in toluene under dry h]chromones/flavones/isoflavones 10, 11, 12 nitrogen conditions in a Dean-Stark trap [27]. were prepared starting from 7-hydroxy-8formyl- and 8-acetylchromones on alkylation with ethyl bromoacetate (Method A) [20-28] or diethyl bromomalonate (Method B) [27, 29-34] in anhydrous acetone or dioxane in the presence of $\mathrm{K}_{2} \mathrm{CO}_{3}$, followed by intramolecular condensation of 7-alkoxy derivatives on active methylene group with 8acyl substituent as shown in examples (Scheme 4). The method B has been improved recently by employment of Ethyl furo[2,3-h]chromone-8-carboxylates $\mathbf{1 1}$ and ethyl 2-(2'-furyl)-3-methylfuro[2,3h]chromone-8-carboxylate prepared by both methods A and B were identical [27]. Hydrolysis of 8-ester group in compounds 11, followed by decarboxylation led to 8unsubstituted furo[2,3-h]chromones 12 [22, 23, 30, 31]. 2,3,5,9- And 2,3,6,9tetramethylfuro[2,3-h]chromones were proposed as potential photochemotherapeutic agents [26].

tetrabutylammonium-bromide (TBAB) as<smiles>[R]C(=O)c1c(O)ccc2c(=O)c([R])c(C)oc12</smiles><smiles>[R]C(=O)c1c(OCC(=O)O)ccc2c(=O)c([R])c(C)oc12</smiles><smiles></smiles>

$\mathrm{R}=\mathrm{H}, \mathrm{Me}, \mathrm{Ph}, \mathrm{R}^{1}=\mathrm{H}, \mathrm{Me}$ $[20,21,26]$<smiles>[R]c1oc2c(C=O)c(O)ccc2c(=O)c1[R]</smiles>

A $\begin{aligned} & \mathrm{BrCH}_{2} \mathrm{CO}_{2} \mathrm{Et}, \mathrm{K}_{2} \mathrm{CO}_{3}, \\ & \text { acetone, } \Delta\end{aligned}$
$\mathrm{R}=\mathrm{Ph}, \mathrm{R}^{1}=\mathrm{OMe}$
B $\underset{\begin{array}{l}\mathrm{Br}\left(\mathrm{CHCO}_{2} \mathrm{Et}\right)_{2}, \mathrm{~K}_{2} \mathrm{CO}_{3}, \\ \text { acetone, } \Delta\end{array}}{\mathrm{R}=\mathrm{Me}, \mathrm{R}^{1}=\mathrm{Ph}}$<smiles>[R]c1oc2c(ccc3oc(C(=O)OCC)cc32)c(=O)c1[R]</smiles>

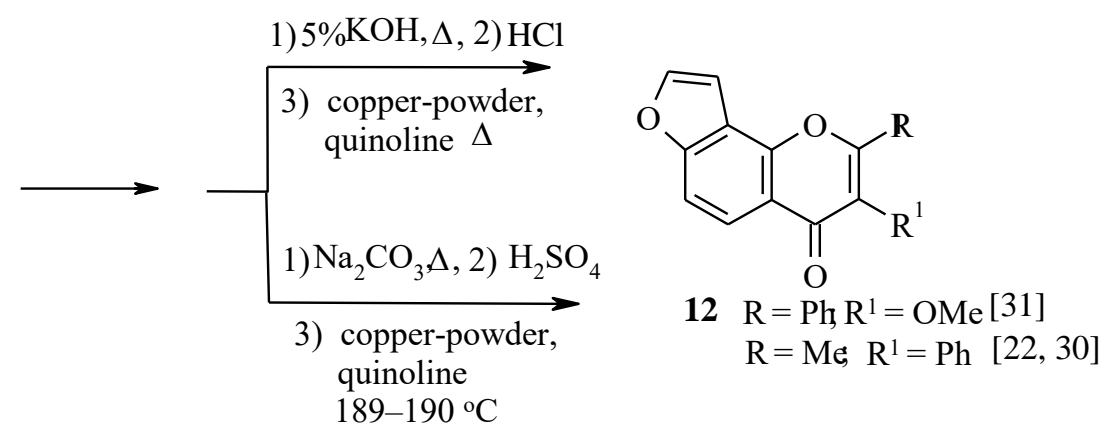

Scheme 4. The synthesis of furo[2,3-h]chromones 
8-(p-Substituted benzoyl)-2-methyl-9phenylfuro[2,3-h]chromones $\mathbf{1 3}$ have been prepared by condensation of 8-benzoyl-7-<smiles>C[14c]1cc(=O)c2ccc(O)c(C(=O)c3ccccc3)c2o1</smiles><smiles>[R]c1ccc(CBr)cc1</smiles>

$\mathrm{R}=\mathrm{H}, \mathrm{Me}, \mathrm{Cl}, \mathrm{MeO}, \mathrm{Ph}, \mathrm{NO}_{2}$ hydroxy-2-methylchromone with various $p$ substituted phenacyl bromides as potential antiimplantation agents. [35, 36] (Scheme 5).

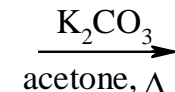<smiles>[R]c1ccc(C(=O)c2oc3ccc4c(=O)cc([Y4])oc4c3c2-c2ccccc2)cc1</smiles>

Scheme 5. The synthesis of 8-aroyl-2-methyl-9-phenylfuro[2,3-h]chromones $\mathbf{1 3}$

\section{Chromones annulated with pyrane cycle}

This section includes the references on the annulation of pyrane, $\alpha$-pyrone, $\gamma$-pyrone and fused pyrane rings to chromone core on the base of 8-carbonyl-7-hydroxychromones.

\subsection{Pyrano[2,3-f]chromones}

\section{Condensation of 8-formyl-7-}

hydroxychromones, flavones, isoflavones and 8-formyl-7-hydroxy-2-(2'-furyl)-3-<smiles>[R]c1oc2c(C=O)c(O)ccc2c(=O)c1[R]</smiles>

$$
\begin{aligned}
& \underset{\mathrm{DABCO}}{\stackrel{\mathrm{R}^{2}-\mathrm{CH}=\mathrm{CH}_{2}}{\longrightarrow}} \\
& 72 \mathrm{~h}, 20^{\circ} \mathrm{C} \\
& \text { inert atmosphere }
\end{aligned}
$$

methylchromone with methyl vinyl ketone, acrolein and acrylonitrile in the presence of diazabicyclo[2.2.2] octane (DABCO) under $\mathrm{N}_{2}$ atmosphere at room temperature using the Baylis-Hillman reaction conditions afforded 9-acetyl/formyl/cyano-substituted pyrano[2,3f]chromones 14 in $65-81 \%$ yields [37-40] (Scheme 6).

$$
\begin{aligned}
& \mathrm{R}=\mathrm{H}, \mathrm{Me}, \mathrm{Ph}, 2-\mathrm{ClC}_{6} \mathrm{H}_{4}, 4-\mathrm{ClC}_{6} \mathrm{H}_{4}, 4-\mathrm{MeOC}_{6} \mathrm{H}_{4}, 2 \text {-furyl } ; \\
& \mathrm{R}^{1}=\mathrm{H}, \mathrm{Me}, \mathrm{Ph}, 4-\mathrm{MeOC}_{6} \mathrm{H}_{4}, 3-\mathrm{ClC}_{6} \mathrm{H}_{4}, 4-\mathrm{BrC}_{6} \mathrm{H}_{4}, 2,4-\mathrm{Cl}_{2} \mathrm{C}_{6} \mathrm{H}_{3} ; \mathrm{R}^{2}=\mathrm{MeCO}, \mathrm{CHO}, \mathrm{CN} \\
& \mathrm{X}=\mathrm{H}, \mathrm{Cl}, \mathrm{Br}
\end{aligned}
$$

Scheme 6. Synthesis of 9-acetyl/formyl/cyanopyrano[2,3-f]chromones 14 via the Baylis-Hillman reaction

A simple and efficient one-pot method has been developed for the synthesis of functionalized pyrano fused flavone derivatives, e.g., such as dialkyl 4-oxo-2- 
phenyl-4,8-dihydropyrano[2,3-f]chromene-

8,9-dicarboxylates

hydroxyflavones
15, from 8-formyl-7using dialkyl- acetalynedicarboxylates in the presence of triphenyl phosphine [41] (Scheme 7).<smiles>[R]c1c(-c2ccccc2)oc2c(C=O)c(O)ccc2c1=O</smiles>

$\mathrm{R}=\mathrm{H}, \mathrm{Me}, \mathrm{Et} ; \mathrm{Alk}=\mathrm{Me}, \mathrm{Et}$<smiles>[R]c1c(-c2ccccc2)oc2c3c(ccc2c1=O)OC(C(=O)O[AlH2])C(C(=O)O[AlH2])=C3</smiles>

Scheme 7. Synthesis of dialkyl 4-oxo-2-phenyl-4,8-dihydropyrano[2,3-f]chromene-8,9-dicarboxylates 15

8-Formyl-7-hydroxy-3-methoxy-

flavone (16) and 2-hydroxy-1-(4hydroxyphenyl)-1-ethanone (17) in ethyl acetate in the presence of $\mathrm{HCl}$ was reported to give 9-hydroxy-8-(4-hydroxyphenyl)-3methoxy-4-oxo-2-phenyl-4H-pyrano[2,3-<smiles>COc1c(-c2ccccc2)oc2c(C(=O)O)c(O)ccc2c1=O</smiles><smiles>[R]c1cc(-c2[o+]c3ccc4c(=O)c(OC)c(-c5ccccc5)oc4c3cc2O)ccc1O</smiles>

$\mathrm{R}=\mathrm{H}, \mathrm{OH}$ f]chromen-7-ium chloride $(\mathbf{1 8})(\mathrm{R}=\mathrm{H})$. Its 3,4dihydroxy analog $18(\mathrm{R}=\mathrm{OH})$ was obtained from flavone 16 and 2-[3,4di(methylcarbonyloxy)phenyl-2-oxoethyl acetate (19) [42] (Scheme 8).

Scheme 8. Synthesis of 9-hydroxy-8-aryl-3-methoxy-4-oxo-2-phenyl-4H-pyrano[2,3-f]chromen-7-ium chlorides 18

\subsection{Chromones annulated with $\alpha$-pyrone} cycle

Annulated with $\alpha$-pyrone cycle at the C7-C8 bound chromones were proposed as potential photoreagents for DNA [43]. $\alpha-$ Pyrono[2,3-f]flavones, their hetero analogues 


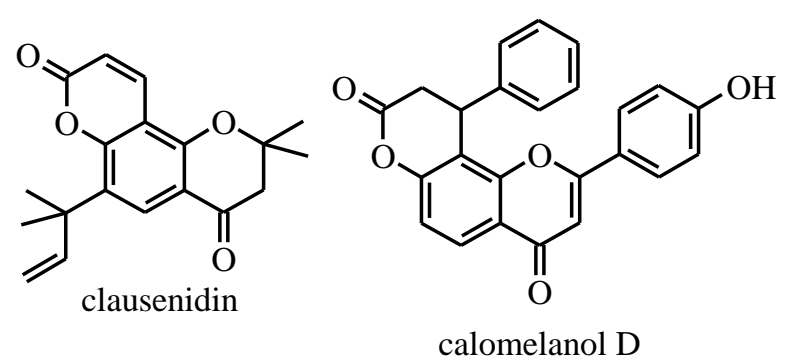

Figure 2. Natural $\alpha$-pyrono[2,3-f]chromones

Annulation of $\alpha$-pyrone cycle to chromone core at the C7-C8 bound starting from 7-hydroxy-8-formylchromones by the Perkin reaction yielded 9-unsubstituted 4H,8H-pyrano[2,3-f]chromen-4,8-diones $\mathbf{2 0}$
[9, 20], $\alpha$-pyrono[2,3-f]flavones [5] and $\alpha$ pyrono[2,3-f]isoflavones [50], while condensation with diethyl malonate, ethyl acetoacetate and cyanoacetic ester under the Knoevenagel conditions gave 9-carbethoxy, 9-acetyl and 9-cyano-4H,8H-pyrano[2,3f]chromen-4,8-diones 21, respectively [20, 43] (Scheme 9). 9-Carbethoxy derivatives 21 $\left(\mathrm{R}^{2}=\mathrm{CO}_{2} \mathrm{Et}\right)$ underwent hydrolysis followed by decarboxylation to give 9-unsubstituted pyrano[2,3-f]chromen-4,8-diones 21 [20, 43].

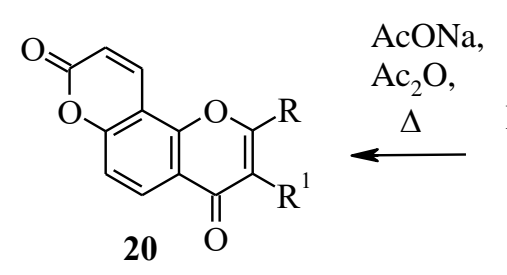

$\mathrm{R}=\mathrm{H}, \mathrm{Me}, \mathrm{Ph}, \mathrm{R}^{1}=\mathrm{H}, \mathrm{MeO}, \mathrm{Ph}$

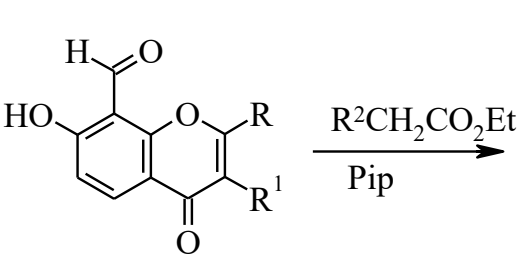<smiles></smiles>

$\mathrm{R}=\mathrm{Me}, \mathrm{R}^{1}=\mathrm{H}, \mathrm{Me}, \mathrm{R}^{2}=\mathrm{CN}, \mathrm{CO}_{2} \mathrm{Et}, \mathrm{Ac}$

Scheme 9. The synthesis of 4H,8H-pyrano[2,3-f]chromen-4,8-diones

The Knoevenagel condensation of 7hydroxy-8-formylchromones with malononitrile depending on the ratio of reagents and conditions used in the reaction led to the variety of the products [51]. Upon treatment of 8-formyl-7-hydroxychromone $\mathbf{2 2}$ with malononitrile $(1: 1)$ in aqueous solution of $\mathrm{NaHCO}_{3}$ 8-iminopyranochromone 23 was isolated in $66 \%$ yield. Subsequent hydrolysis of the compound 23 via refluxing in $\mathrm{AcOH}$ resulted in pyranochromone $\mathbf{2 4}$ formation in $75 \%$ yield. (Scheme 10).
Conducting the Knoevenagel reaction of the compound $\mathbf{2 5}$ in acetic acid resulted in 4H,8H-pyrano[2,3-f]chromen-4,8-dione $\mathbf{2 6}$ in $50 \%$ yield without isolation of intermediate 8imino derivative (Scheme 10).

Having already been isolated, 8iminopyranochromone $\mathbf{2 3}$ was envisaged to be able to join another malononitrile molecule at $\mathrm{C} 10$ through the Michael addition. Thus, using of 2 equivalents of malononitrile in reaction with 8 -formylchromone $\mathbf{2 2}$ in methanol and $\mathrm{Et}_{3} \mathrm{~N}$ gave the product 27 in 60\% yield (Scheme 10). 

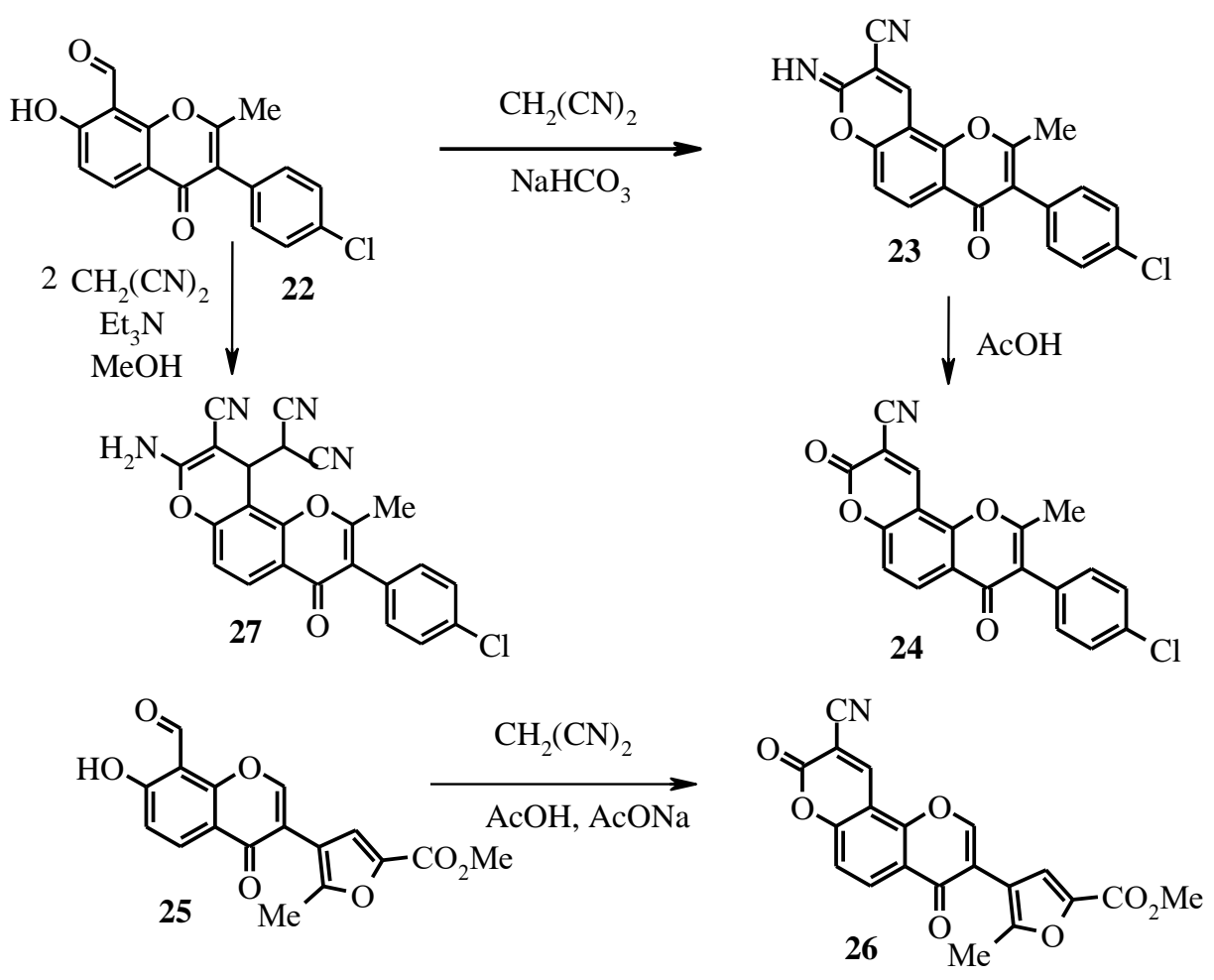

Scheme 10. The interaction of 8-formyl-7-hydroxychromones with malononitrile

Condensation of 8-formyl-7hydroxyisoflavones and 8-formyl-7-hydroxy3-aryloxychromones 28 with hetarylacetonitriles in the Knoevenagel conditions makes it possible to introduce heterocyclic substituent in 9-th position of 4H,8H-pyrano[2,3-f]chromen-4,8-diones

29 [8-11, 52-54] (Scheme 11). 3,9-Disubstituted with different heterocycles $4 \mathrm{H}, 8 \mathrm{H}$ pyrano[2,3-f]chromen-4,8-diones $\mathbf{2 9}$ can be synthesized by the reaction of 3-hetaryl-8formyl-7-hydroxychromones 28 with hetarylacetonitriles. In a number of cases, the intermediates of this reaction 9-azahetaryl-8iminopyrano[2,3-f]chromen-4-ones were isolated. The desired products 29 were obtained by hydrolysis of the latter in a mixture of hydrochloric and acetic acids (Scheme 11). 
<smiles>[R]c1oc2c(ccc3oc(=O)c(CC)cc32)c(=O)c1[R]</smiles>

$\mathrm{R}^{1}=\mathrm{H}, \mathrm{Me}, \mathrm{CF}_{3}$<smiles>[R][N+](=O)O[Na]</smiles><smiles>CCc1cc(C)nc(C)n1</smiles>

Scheme 11. The synthesis of 9-hetaryl-4H,8H-pyrano[2,3-f]chromen-4,8-diones 29

A facile synthesis of 3-aroylcoumarinflavone hybrids $\mathbf{3 0}$ was implemented by interaction of 8-formyl-7-hydroxyflavones $\mathbf{3 1}$<smiles>[X]c1ccc(C(=O)C=C(SC)SC)cc1</smiles>

and $\alpha$-oxoketene dithioacetals in the presence of a catalytic amount of piperidine [55] (Scheme 12).

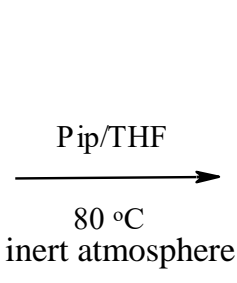<smiles>[X]c1ccc(C(=O)c2cc3c(ccc4c(=O)cc(-c5ccc([X])cc5)oc43)oc2=O)cc1</smiles>

Scheme 12. The synthesis of 3-aroylcoumarin-flavone hybrids 30

\subsection{Chromones annulated with $\gamma$-pyrone} cycle

4H,10H-Pyrano[2,3-f]chromen-4,10-

dione system is a skeleton of light-yellow dyes for silk arthraxin and norarthraxin
(Figure 3), which were isolated from Arthraxon histidus Makino and Miscantus tinctorius Hacke [56-59]. Derivatives of this system revealed higher light-stability than natural analogues $[60,61]$. They have been 
proposed as liquid crystals [62] and antiallergic agents $[63,64]$. They were active in treating extrinsic allergic asthma, intrinsic asthma, hay fever, urticaria and auto-immune diseases [65] and were patented as antihistaminic [66] and antiasthmatic agents [67-69].<smiles>CC(O)Cc1oc2cc(O)c3c(=O)cc(-c4ccc(O)c(O)c4)oc3c2c(=O)c1O</smiles>

arthraxin<smiles>O=c1cc(-c2ccc(O)c(O)c2)oc2c1c(O)cc1occ(O)c(=O)c12</smiles>

norarthraxin

Figure 3. Natural $\boldsymbol{\gamma}$-pyrono[2,3-f]chromones

Design of $4 H, 10 H$-pyrano[2,3f]chromen-4,10-dione system can be accomplished both by simultanious annelation of the two $\gamma$-pyrone rings to benzene core and by annelation of $\gamma$-pyrone ring to chromone system. The advantage of the second approach is a possibility to obtain the system with different substituents in pyrone cycles. Three ways to $4 H, 10 H$-pyrano[2,3f]chromen-4,10-diones based on 8-acetyl-7hydroxychromones are described in the literature.
The first one is the Kostanecki reaction. Condensation of 8-acetyl-7hydroxy-2-methylchromone $\mathbf{3 2}$ with acetic anhydride and anhydrous sodium acetate yielded 9-acetoxy-2,8-dimethyl-4H,10Hpyrano[2,3-f]chromen-4,10-dione 33, which underwent smooth deacetylation when boiling with aqueous sodium carbonate giving 9unsubstituted product 34 [20, 70] (Scheme 13). 8-Propionylchromone $\mathbf{3 5}$ in the Kostanecki reaction conditions forms 2,3,8,9tetramethyl-4H,10H-pyrano[2,3-f]chromen4,10-dione 36 [15] (Scheme 13).

Flavon 37, with a skeleton similar to artraxin, was prepared by heating 8-acetyl5,7-dihydroxyflavon $\mathbf{3 8}$ with benzoic anhydride and $\mathrm{BzONa}$ at $180^{\circ} \mathrm{C}$ [71] (Scheme 13).<smiles>[R]C1=CC(=O)c2ccc3oc(C)c(C)c(=O)c3c2C1=O</smiles><smiles>CCC(=O)c1c(O)ccc2c(=O)c(C)c(C)oc12</smiles><smiles>CC(=O)c1c(O)cc(O)c2c(=O)cc(-c3ccccc3)oc12</smiles>

Scheme 13. The synthesis of $4 H, 10 H$-pyrano[2,3f]chromen-4,10-diones via the Kostanecki reaction 
The second way relies upon the Claisen reaction (the condensation of acetyl chromones with esters). 8-Acetyl-7-hydroxy3-methylflavon 39 when heating with diethyloxalate in methanol in the presence of $\mathrm{MeONa}$ cyclized into 4H,10H-pyrano[2,3f]chromen-4,10-dione 40 [64] (Scheme 14).

The third receiving path to $4 H, 10 H$ pyrano[2,3-f]chromen-4,10-dione system (41) is the enaminokethone method, which comprises in the interaction of 8-acetyl-7hydroxyisoflavone $\mathbf{4 2}$ with $\mathrm{N}, \mathrm{N}-$ dimethylformamide dimethyl acetal in toluene, followed by cyclization of 8-(3dimethylamino-2-propenoyl)-7-hydroxy-4Hchromen-4-one $\mathbf{4 3}$ in acetic acid [72] (Scheme 15).<smiles></smiles>

Scheme 14. The synthesis of $4 H, 10 H$-pyrano[2,3f]chromen-4,10-dione $\mathbf{4 0}$ via the Claisen reaction<smiles>CCc1cc2c(=O)c(-c3ccc(Cl)cc3)c(C)oc2c(C(C)=O)c1O</smiles>

42<smiles>CCc1cc2c(=O)c(-c3ccc(Cl)cc3)c(C)oc2c(CC(=O)O)c1O</smiles>

43<smiles>CCc1cc2c(=O)c(-c3ccc(Cl)cc3)c(C)oc2c2c(=O)ccoc12</smiles>

41

Scheme 15. The enaminokethone method of synthesis of 4H,10H-pyrano[2,3-f]chromen-4,10-dione 41

\subsection{Chromones annulated with the system of fused pyrane and other rings}

Chromones annelated with pyran ring, fused with pyridin and piperidin cycles are represented by alkaloids, such as schumanniophytine $\mathbf{4 4}$, schumannificine $\mathbf{4 5}$, anhydrochumannificine 46, schumagnine 47, isolated from plants of Schumanniophyton genus in the family Rubiaceae [73-75] (Figure 4). The alkaloids of Schumanniophyton genus were found to possess antiviral activity against human immunodeficiency virus (HIV) [76]. 
<smiles>Cc1cc(=O)c2c(O)cc3oc(=O)c4cnccc4c3c2o1</smiles>

44

schumanniophytine<smiles>Cc1cc(=O)c2c(O)cc3c(c2o1)C1CCNC(=O)C1[C@H](O)O3</smiles>

45

schumannificine<smiles>Cc1cc(=O)c2c(O)cc3c(c2o1)C1CCNC(=O)C1=CO3</smiles>

46

anhydroschumannificine<smiles>Cc1cc(=O)c2c(O)cc3c(c2o1)[C@H]1CCN[C@H](C1)O3</smiles>

47

schumagnine

Figure 4. Structures of alkaloids from plants of Schumanniophyton genus

The Hantzsch reaction has been successfully employed to one-step assembling pyrano-pyridine fragment to chromone core to give isomeric to schumanniophytine skeleton structure 48 with antibacterial activity [77]. 8Formyl-7-hydroxychromones 49 in the reaction with ethyl 3-aminocrotonate in acetic acid medium quantitatively yielded $5 H, 9 H$ - pyrano[2',3':5,6]chromeno[4,3-b]pyridine-

5,9-diones 48 [77], while 7-methoxy-8formylflavones $\mathbf{5 0}$ under the same conditions afforded 7-methoxy-2-aryl-3-(phenyl/or-H)-8[2-(4,6-dimethyl-3,5-dicarbethoxypyridyl)]4H-1-benzopyran-4-ones 51 [78] (Scheme 16).

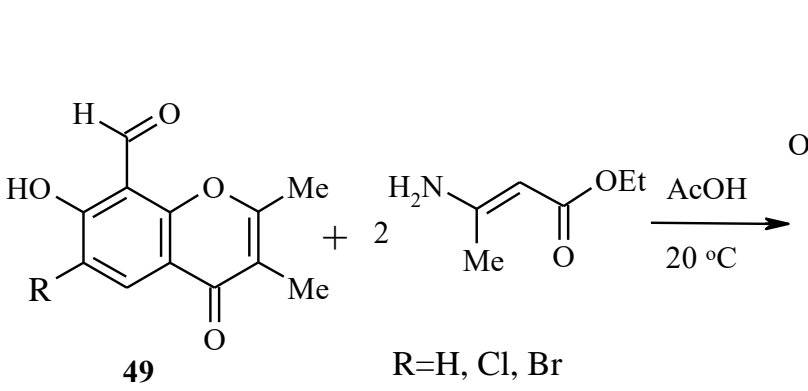

49 $\mathrm{R}=\mathrm{H}, \mathrm{Cl}, \mathrm{Br}$<smiles>[R]c1cc2c(=O)c(C)c(C)oc2c2c1oc(=O)c1c(C)c(C(=O)OCC)c(C)c([R])c12</smiles><smiles>[X]c1ccc(-c2oc3c(-c4nc(C)c(C(=O)OCC)c(C)c4C(=O)OCC)c(OC)ccc3c(=O)c2[R])cc1</smiles>

Scheme 16. The synthesis of 5H,9H-pyrano[2',3':5,6]chromeno[4,3-b]pyridine-5,9-diones $\mathbf{4 8}$ and 7-methoxy-8-[2-(4,6dimethyl-3,5-dicarbethoxypyridyl)]-4H-1-benzopyran-4-ones $\mathbf{5 1}$ via the Hantzsch reaction 
Pyrano[2',3':5,6]chromeno[4,3-b]-

quinolin-4-ones $\mathbf{5 2}$ have been synthesized from 8-formyl-7-hydroxy-2-methylchromone and isoflavone in two steps: by alkylation with 2-propynyl bromide to give 8-formyl-7(prop-2-ynyloxy)-2,3-disubstituted

chromones $\mathbf{5 3}$ followed by intramolecular aza-Diels-Alder reaction of the azadienes generated in situ from aryl amines and 8formyl-7-(prop-2-ynyloxy)chromones

\section{3}

using $\mathrm{CuFe}_{2} \mathrm{O}_{4}$ nanoparticles as a catalyst in DMSO at $80-90^{\circ} \mathrm{C}$ in good-to-excellent yields [79] (Scheme 17). 2-Chloranilines form 13Cl-substituted products 52, 4-substituted anilines form 11-substituted products $\mathbf{5 2}$ and 3-methoxyanilines give the mixture of 10methoxy and $12-$ methoxypyrano[2',3':5,6]chromeno[4,3b]quinolin-4-ones (52).<smiles>[R]c1c(C)oc2c(C(=O)O)c(O)ccc2c1=O</smiles><smiles>[X]c1ccc(N)cc1</smiles><smiles>[R]c1c(C)oc2c(C=O)c(OCC#C)ccc2c1=O</smiles>

53

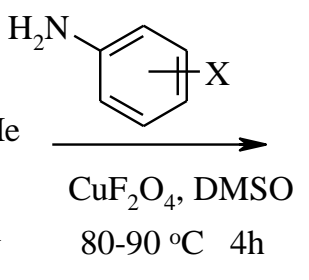

$80-90{ }^{\circ} \mathrm{C} \quad 4 \mathrm{~h}$

$\mathrm{X}=\mathrm{H}, 2-\mathrm{Cl}$, 4-Me, 4-MeO, 4-Br, 4-F, 3-MeO

Scheme 17. The synthesis of pyrano[2',3':5,6]chromeno[4,3-b]quinolin-4-ones 52

7-O-prenyl derivatives of 8 -formyl2,3-disubstituted chromones $\mathbf{5 4}$, synthesized by alkylation of subsequent 8-formyl-7hydroxychromones with prenyl bromide, as well as 7-(prop-2-ynyloxy) derivatives $\mathbf{5 3}$ are usefull synthones for intramolecular hetero Diels-Alder reaction [80].<smiles>[R]c1oc2c(C([2H])=O)c(O)ccc2c(=O)c1[R]</smiles>

$\mathrm{R}^{1}=\mathrm{H}, \mathrm{Ph}$

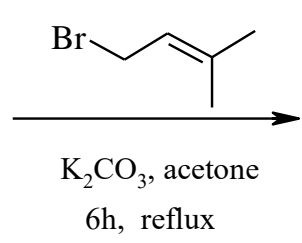

$\mathrm{R}^{2}=\mathrm{Me}, \mathrm{Ph}$<smiles>[R]c1oc2c(C(=O)O)c(OCC=C(C)C)ccc2c(=O)c1[R]</smiles>

54<smiles>[R]c1c(C)oc2c3c(ccc2c1=O)OCc1cc2cccc([X])c2nc1-3</smiles>

$\mathrm{R}=\mathrm{Me}, \mathrm{Ph}$

Scheme 18. The synthesis of 7- $O$-prenyl-8-formyl-2,3-disubstituted chromones $\mathbf{5 4}$ 
A series of articles [80-83] is devoted to the synthesis of $\mathrm{O}, \mathrm{N}$-containing hetarenopyrano[2,3-f]chromones via intramolecular hetero Diels-Alder reaction and their biological activity. Cis-fused tetrahydrochromeno[4,3-b]quinolines

55-57 have been synthesized by intramolecular
[4+2] imino-Diels-Alder reactions of 2azadienes derived in situ from aromatic amines and 7-O-prenyl derivatives of 8formyl-2,3-disubstituted chromones $\mathbf{5 4}$ in the presence of $20 \mathrm{~mol} \% \quad \mathrm{Yb}(\mathrm{OTf})_{3} \quad$ in acetonitrile under reflux in good to excellent yields [81] (Scheme 19).<smiles>[R]c1oc2c(C(=O)O)c(OCC=C(C)C)ccc2c(=O)c1[R]</smiles><smiles>Nc1ccc2ccccc2c1</smiles>

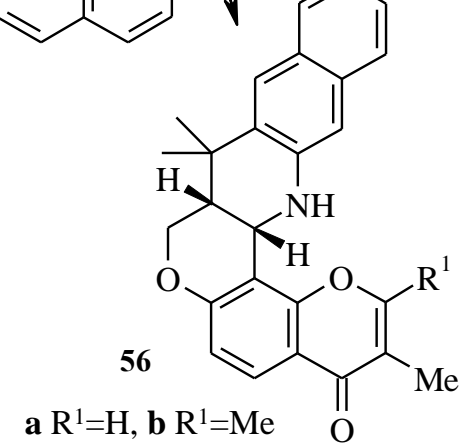<smiles>[R]c1ccc(N)cc1</smiles><smiles>[CH]C1CC1</smiles>
$\mathrm{NH}_{2}$<smiles>Nc1cccc2ccccc12</smiles><smiles>C[Tl]</smiles><smiles>Cc1coc2c3c(ccc2c1=O)OC[C@H]1[C@@H](C)c2ccc4ccccc4c2N[C@@H]31</smiles><smiles>[R]c1ccc2c(c1)C(C)(C)[C@@H]1COc3ccc4c(=O)c([R])c([R])oc4c3[C@@]1(C)N2</smiles>

a $\mathrm{R}=\mathrm{R}^{1}=\mathrm{R}^{2}=\mathrm{Me}$ b $\mathrm{R}=\mathrm{MeO}, \mathrm{R}^{1}=\mathrm{R}^{2}=\mathrm{Me}$ c $\mathrm{R}=\mathrm{H}, \mathrm{R}^{1}=\mathrm{R}^{2}=\mathrm{Me}$ d $\mathrm{R}=\mathrm{R}^{2}=\mathrm{Me}, \mathrm{R}^{1}=\mathrm{H}$ e $\mathrm{R}=\mathrm{R}^{1}=\mathrm{H}, \mathrm{R}^{2}=\mathrm{Me}$ f $\mathrm{R}=\mathrm{Br}, \mathrm{R}^{1}=\mathrm{H}, \mathrm{R}^{2}=\mathrm{Me}$ g $\mathrm{R}=\mathrm{R}^{1}=\mathrm{Me}, \mathrm{R}^{2}=\mathrm{Ph}$ h $\mathrm{R}=\mathrm{H}, \mathrm{R}^{1}=\mathrm{Me}, \mathrm{R}^{2}=\mathrm{Ph}$

i: $\mathrm{Yb}(\mathrm{OTf})_{3}$, acetonitrile, 3-3,5 h, reflux

Scheme 19. The synthesis of $c i s$-fused tetrahydrochromeno[4,3-b]quinolines 55- 57 via intramolecular [4+2] imino-Diels-Alder reaction.

These compounds were evaluated for their antiproliferative activity against MDAMB-231 and MCF-7 breast cancer cells. The results showed that compounds $57,55 \mathbf{a}$ and $\mathbf{5 5 h}$ exhibit significant antiproliferative activity against MCF-7 breast cancer cells and low inhibitory activity against MDAMB-231 breast cancer cell lines. Compound 56a displayed activity as comparable to tamoxifen on both the cell lines [81].
Cis-fused chromeno pyrano[4,3c]isoxazole derivatives $\mathbf{5 8}$ have been synthesized by intramolecular [1,3]cycloaddition of the nitrones generated in situ from hydroxylamine derivatives and 7-Oprenyl-8-formyl-2,3-disubstituted chromones 54 using PEG-400 as a reaction medium under catalyst-free conditions in 72-90\% yields [82] (Scheme 20). The results showed that compounds $\mathbf{5 8 b}, \mathbf{5 8 c}, \mathbf{5 8 d}, \mathbf{5 8 e}$ and $\mathbf{5 8 k}$ 
exhibit very potent antiproliferative activity against MDA-MB-231 breast cancer cells. Compounds 58a, 58c, 58e, 58i and 58k displayed potent inhibitory activity against human MCF-7 breast cancer cell lines. Compounds $\mathbf{5 8 h}$ and $\mathbf{5 8 i}$ exhibited significant antiproliferative activity against human cervical cancer cell line, HeLa. While 58b, 58d and 58j were active against human lung cancer cell line, A549. Compound 58j was found to be the most promising against A549 (Lung cancer) with IC50 value of $0.194 \mu \mathrm{M}[82]$.<smiles>[R]c1oc2c(C=O)c(OCC=C(C)C)ccc2c(=O)c1[R]</smiles>

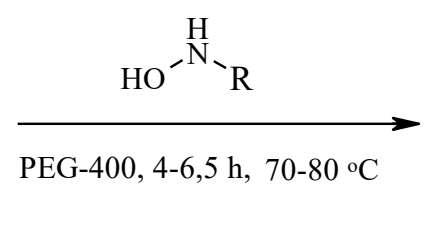

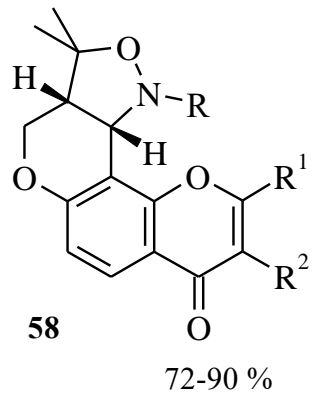

58 a $\mathrm{R}=\mathrm{PhCH}_{2}, \mathrm{R}^{1}=\mathrm{R}^{2}=\mathrm{Me} ; \boldsymbol{b} \mathrm{R}=$ cyclohexyl, $\mathrm{R}^{1}=\mathrm{R}^{2}=\mathrm{Me} ; \mathbf{c} \mathrm{R}=4-\mathrm{MeOC}_{6} \mathrm{H}_{4} \mathrm{CH}_{2}, \mathrm{R}^{1}=\mathrm{R}^{2}=\mathrm{Me}$; d $\mathrm{R}=4-\mathrm{MeC}_{6} \mathrm{H}_{4} \mathrm{CH}_{2}, \mathrm{R}^{1}=\mathrm{R}^{2}=\mathrm{Me}$; e R=i- $\mathrm{PrC}_{6} \mathrm{H}_{4} \mathrm{CH}_{2}, \mathrm{R}^{1}=\mathrm{R}^{2}=\mathrm{Me} ; \mathbf{f} \mathrm{R}=4-\mathrm{FC}_{6} \mathrm{H}_{4} \mathrm{CH}_{2}, \mathrm{R}^{1}=\mathrm{R}^{2}=\mathrm{Me}$; g 2,3,4-(MeO) ${ }_{3} \mathrm{C}_{6} \mathrm{H}_{2} \mathrm{CH}_{2}, \mathrm{R}^{1}=\mathrm{R}^{2}=\mathrm{Me} ; \mathbf{h} \mathrm{R}=\mathrm{PhCH}_{2}, \mathrm{R}^{1}=\mathrm{H}, \mathrm{R}^{2}=\mathrm{Me} ; \mathbf{i} \mathrm{R}=$ cyclohexyl, $\mathrm{R}^{1}=\mathrm{H}, \mathrm{R}^{2}=\mathrm{Me}$; j R=4-MeOC ${ }_{6} \mathrm{H}_{4} \mathrm{CH}_{2}, \mathrm{R}^{1}=\mathrm{H}, \mathrm{R}^{2}=\mathrm{Me} ; \mathbf{k} \mathrm{R}=4-\mathrm{MeC}_{6} \mathrm{H}_{4} \mathrm{CH}_{2}, \mathrm{R}^{1}=\mathrm{H}, \mathrm{R}^{2}=\mathrm{Me} ; \mathbf{I} \mathrm{R}=4-\mathrm{MeOC}_{6} \mathrm{H}_{4} \mathrm{CH}_{2}, \mathrm{R}^{1}=\mathrm{Me}, \mathrm{R}^{2}=\mathrm{Ph}$

Scheme 20. The synthesis of chromeno-annulated cis-fused pyrano[4,3-c]isoxazole derivatives $\mathbf{5 8}$ via intramolecular nitrone cycloaddition

A series of chromeno-annulated cisfused pyrano[3,4-c]pyran derivatives $\mathbf{5 9 - 6 3}$ have been synthesized by intramolecular [4+2] domino Knoevenagel-hetero-DielsAlder reactions of 1-oxa-1,3-butadienes derived in situ from 1,3-dicarbonyls/active methylenes and 7-O-prenyl derivatives of 8formyl-2,3-disubstituted chromenones 54 in the presence of $20 \mathrm{~mol} . \%$ ethylenediamine diacetate (EDDA) in acetonitrile under reflux in $80-95 \%$ yields [80] (Scheme 21). 
<smiles></smiles>

a $\mathrm{R}^{2}=\mathrm{Me}, \mathbf{b} \mathrm{R}^{2}=\mathrm{Ph}$<smiles>[Z]C1([Z](C)C)CC(=O)CC(=O)C1</smiles><smiles>[R]c1oc2c3c(ccc2c(=O)c1[R])OC[C@H]1[C@@H]([2H])OC2=C(C(=O)CC([R])([R])C2)[C@@H]31</smiles>

a $\mathrm{R}^{1}=\mathrm{R}^{2}=\mathrm{Me}, \mathrm{R}^{3}=\mathrm{R}^{4}=\mathrm{H} ; \mathbf{b ~ R}^{1}=\mathrm{R}^{3}=\mathrm{R}^{4}=\mathrm{H}, \mathrm{R}^{2}=\mathrm{Me}$; c $\mathrm{R}^{1}=\mathrm{Me}, \mathrm{R}^{2}=\mathrm{Ph}, \mathrm{R}^{3}=\mathrm{R}^{4}=\mathrm{H}, \mathbf{d ~ R}^{1}=\mathrm{R}^{2}=\mathrm{R}^{3}=\mathrm{R}^{4}=\mathrm{Me}$; e $\mathrm{R}^{1}=\mathrm{R}^{3}=\mathrm{R}^{4}=\mathrm{Me}, \mathrm{R}^{2}=\mathrm{H}$

i: EDDA, acetonitrile, reflux<smiles>[R]c1oc2c(C=O)c(OCC=C(C)C)ccc2c(=O)c1[R]</smiles><smiles>CC1=NN(c2ccccc2)C(=O)C1</smiles><smiles>CC1(C)OC(=O)CC(=O)O1</smiles><smiles>[R]C(=O)CC(C)=O</smiles><smiles>[R]c1c(C)oc2c3c(ccc2c1=O)OC[C@H]1[C@H](C)OC2[C@@H](C(C)=NN2c2ccccc2)[C@@H]31</smiles>
a $\mathrm{R}^{2}=\mathrm{Me}, \mathbf{b} \mathrm{R}^{2}=\mathrm{Ph}$<smiles>[R]c1oc2c3c(ccc2c(=O)c1C)OC[C@H]1[C@@H]3CC(=O)OC(C)(C)[C@@H]1C</smiles>

a $\mathrm{R}^{1}=\mathrm{Me}, \mathbf{b}^{1}=\mathrm{H}$<smiles>[R]C(=O)C1=C(C)OC(C)C2COc3ccc4c(=O)c(C)c(C)oc4c3C12</smiles>

a $\mathrm{R}=\mathrm{Me}, \mathbf{b} \mathrm{R}=\mathrm{EtO}$

Scheme 21. The synthesis of chromeno-annulated cis-fused pyrano[3,4-c]pyran derivatives 59-63 via intramolecular [4+2] domino Knoevenagel-hetero-Diels-Alder reaction

These compounds were evaluated for their antiproliferative activity using an in vitro MTT cytotoxicity assay. The results clearly demonstrated that compounds 59a, 59b, 60a, 61b, 62a, 62b, 63a and 63b exhibited significant anti-proliferative activity against human A549 lung cancer and non-cancer MRC-5 cell lines along with potent inhibitory activity against human neuroblastoma SK-NSH cancer cell lines. Among these, compounds 59a, 59b and 61b displayed the most potent anti-proliferative activity against human lung cancer A549 cell lines, while 59a and 59b displayed activity against neuroblastoma SK-N-SH cancer cell lines when compared to the standard doxorubicin [80].

Reaction of 54 and 2,4-chromanedione gave the mixture of the fused pyranobenzopyranones $64(80 \%)$ and 65 (5\%) (Scheme 22) [80]. 
<smiles>[R]c1oc2c(C=O)c(OCC=C(C)C)ccc2c(=O)c1[R]</smiles><smiles>O=C1CC(=O)c2ccccc2O1</smiles><smiles>Cc1oc2c3c(ccc2c(=O)c1C)OC[C@H]1[C@@H]3c2c(c3ccccc3oc2=O)OC1(C)C</smiles>

$64(80 \%)$<smiles>Cc1oc2c3c(ccc2c(=O)c1C)OC[C@H]1[C@@H]3c2c(oc3ccccc3c2=O)OC1(C)C</smiles>

$65(5 \%)$

Scheme 22. The synthesis of fused pyranobenzopyranones 64,65 .

Chromeno-annulated pyrano[3,4-c]benzopyran cis-fused

66 and naphthopyran 67 derivatives have been synthesized from 7-O-prenyl-8formylchromones $\mathbf{5 4}$ and resorcinols or naphthols under the same conditions in good yields [83]. The compounds $66 \mathrm{~g}$ and $67 \mathbf{b}$ exhibited very potent cytotoxicity against human cervical cancer cell line (HeLa).
Compound 66g displayed good inhibitory activity against both breast cancer cell lines, MDA-MB-231 and MCF-7. Further, the compound 66h exhibited good cytotoxicity against only MDA-MB-231, and compound 67b showed promising activity against human lung cancer cell line, A549 with IC50value of $2.53 \pm 0.07 \mu \mathrm{M}$, which was comparable to the standard doxorubicin $(\mathrm{IC} 50=1.21 \pm 0.1 \mu \mathrm{M})$.<smiles>[R]c1oc2c3c(ccc2c(=O)c1C)OC[C@H]1[C@@H](C)Oc2c(ccc4ccccc24)[C@H]3[C@H]1C</smiles>

a $\mathrm{R}^{1}=\mathrm{Me}, \mathbf{b ~ R}^{1}=\mathrm{H}$

i: EDDA, acetonitrile, reflux $12 \mathrm{~h}, 80-85^{\circ} \mathrm{C}$<smiles>[R]c1oc2c(C(=O)O)c(OCC=C(C)C)ccc2c(=O)c1[R]</smiles><smiles>[R]C(=O)c1ccc(O)cc1O</smiles>

66<smiles>[R]C(=O)c1ccc2c(c1O)[C@H]1c3c(ccc4c(=O)c([R])c([R])oc34)OC[C@H]1C(C)(C)OC2</smiles>

66 a $\mathrm{R}=\mathrm{Et}, \mathrm{R}^{1}=\mathrm{R}^{2}=\mathrm{Me} ; \mathbf{b} \mathrm{R}=\mathrm{Me}, \mathrm{R}^{1}=\mathrm{R}^{2}=\mathrm{Me}$; c $\mathrm{R}=\mathrm{PhCH}_{2}, \mathrm{R}^{1}=\mathrm{R}^{2}=\mathrm{Me} ; \mathbf{d} \mathrm{R}=\mathrm{Ph}, \mathrm{R}^{1}=\mathrm{R}^{2}=\mathrm{Me}$; e $\mathrm{R}=\mathrm{Et}, \mathrm{R}^{1}=\mathrm{H}, \mathrm{R}^{2}=\mathrm{Me}$; $\mathbf{f}=\mathrm{Me}, \mathrm{R}^{1}=\mathrm{H}, \mathrm{R}^{2}=\mathrm{Me}$; g $\mathrm{R}=\mathrm{PhCH}_{2}, \mathrm{R}^{1}=\mathrm{H}, \mathrm{R}^{2}=\mathrm{Me} ; \mathbf{h} \mathrm{R}=\mathrm{Ph}, \mathrm{R}^{1}=\mathrm{H}, \mathrm{R}^{2}=\mathrm{Me}$; i $\mathrm{R}=\mathrm{Et}, \mathrm{R}^{1}=\mathrm{Me}, \mathrm{R}^{2}=\mathrm{Ph} ; \mathrm{j} \mathrm{R}=\mathrm{R}^{1}=\mathrm{Me}, \mathrm{R}^{2}=\mathrm{Ph}$

Scheme 23. The synthesis of chromeno-annulated cis-fused pyrano[3,4-c]benzopyran 66 and naphthopyran 67 derivatives via domino aldol-type/hetero Diels-Alder reaction 


\section{N-Containing fused chromones}

In respect that furanochromones have been shown to posses a wide range of physiological properties $[18,19]$, on analogy of these, the synthesis of a few isoxazolo[7,8d]flavones $\mathbf{6 8}$ has been undertaken with the expectation that these compounds may possess biological activity [84]. Isoxazolo[7,8-d]flavones $\mathbf{6 8}$ have been synthesized from 8-acetyl- and 8-formyl-7hydroxyflavones and hydroxylamine hydrochloride via preparing the oximes 69 and next following cyclizing with concentrated sulphuric acid at room temperature. In the case of 3-metylflavones, warming on the water-bath has been found to be necessary to effect cyclization. [84]

\section{(Scheme 24).}<smiles>[R]C(=O)c1c(O)ccc2c(=O)c([R])c([Al])oc12</smiles><smiles>CC(C)(C)[C@H](N)O[Na]</smiles>

$\mathrm{R}=\mathrm{H}, \mathrm{Me} ; \mathrm{R}^{\prime}=\mathrm{H}, \mathrm{Me}$; $\mathrm{Ar}=\mathrm{Ph}, 4-\mathrm{ClC}_{6} \mathrm{H}_{4}, 4-\mathrm{Me} \mathrm{C}_{6} \mathrm{H}_{4}, 4-\mathrm{MeOC}_{6} \mathrm{H}_{4}, 4-\mathrm{NO}_{2} \mathrm{C}_{6} \mathrm{H}_{4}, 3,4,5-(\mathrm{MeO})_{3} \mathrm{C}_{6} \mathrm{H}_{2}$,

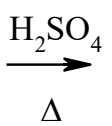<smiles>[R]c1c([Al])oc2c(ccc3onc([R])c32)c1=O</smiles>

Scheme 24. The synthesis of isoxazolo[7,8-d]flavones 68

The antibacterial activity of isoxazolo[7,8-d]flavones $\mathbf{6 8}$ have been evaluated using Staphylococcus aureus, Bacillus coli and Bacillus subtilis. Of the compounds tested, 3-methylisoxazolo[7,8d]flavone and 4'-chloroisoxazolo[7,8d]flavone exhibited the maximum activity, inhibiting the growth of all the bacteria at $10 \mathrm{ppm}$. In general, the 3methylisoxazolo[7,8-d]flavone derivatives $\mathbf{6 8}$ have shown greater activity than thous without this substituent [84].

Annulation of pyrazole cycle to chromone system has been implemented on the basis of 8-acetyl- and 8-formyl-7hydroxychromones $\mathbf{7 0}, \mathbf{7 1}$. Their treatment with 2-(mesitylene)sulfonyl chloride in dry $\mathrm{CH}_{2} \mathrm{Cl}_{2}$ in the presence of $\mathrm{Et}_{3} \mathrm{~N}$ and catalytic amount of 4-dimethylamino pyridine resulted in esters 72 and 73, which under nucleophilic substitution by hydrazine hydrate in $\mathrm{EtOH}$ (73) or in the mixture of toluene and $\mathrm{EtOH}$ (72) in the presence of $\mathrm{MgSO}_{4}$ and $\mathrm{AcONH}_{4}$ on heating in microwave tube at $145^{\circ} \mathrm{C}$ $(80 \mathrm{~min})$ or $140^{\circ} \mathrm{C} \quad(2 \mathrm{~h}), \quad$ respectively, provided the corresponding (un)substituted at position 9 pyrano[2,3-e]indazol-4-(7H)-one 74 и 75 [85] (Scheme 25). 


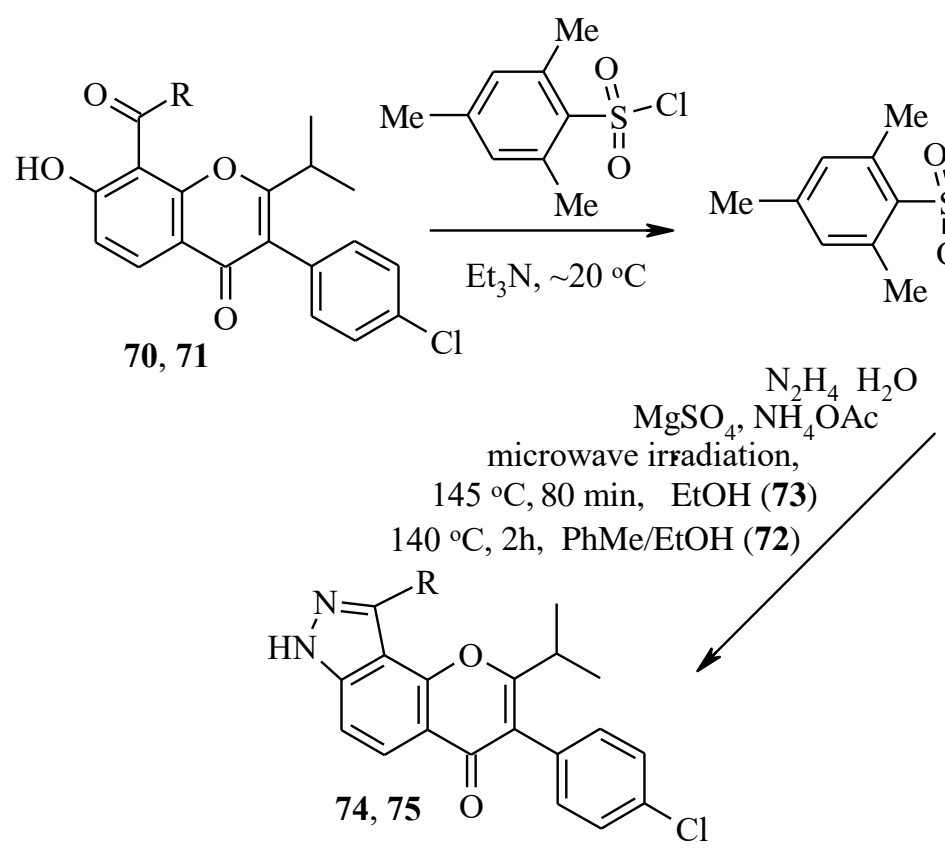

70, 72, $74 \mathrm{R}=\mathrm{Me} ; \mathbf{7 1}, \mathbf{7 3}, 75 \mathrm{R}=\mathrm{H}$<smiles>[R]C(=O)c1c(OC)ccc2c(=O)c(-c3ccc(Cl)cc3)c(C(C)C)oc12</smiles>

72,73

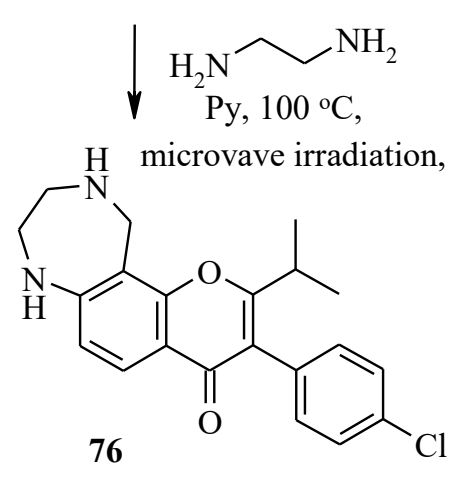

Scheme 25. The synthesis of chromones annelated with pyrazole and diazepine cycles

A mixture of 2,4,6- structure 77 and named aspergillitine [86] trimethylbenzenesulfonic acid 3-(4- (Figure 5).

chlorophenyl)-8-formyl-2-isopropyl-4-oxo-

4H-chromen-7-yl ester (73) and ethylene diamine in anhydrous pyridine in a sealed microwave tube was heated under microwave irradiation to give hexahydrochromeno[7,8e][1,4]diazepin-4-one 76 [85] (Scheme 25). Chromones annulated with pyrazole $(\mathbf{7 4}, \mathbf{7 5})$ and diazepin rings $(\mathbf{7 6})$ at $\mathrm{C}(7)-\mathrm{C}(8)$ bond were patented as antagonists of VRI receptors [85].

In 2003, a novel tricyclic angular chromone, containing pyridine ring was isolated from the marine fungus Aspergillus versicolor. It was reported to have the<smiles>Cc1cc2ccc3c(=O)c(C)c(C)oc3c2cn1</smiles>

aspergillitine<smiles>CC(C)=C1Oc2c(ccc3cc(C)ncc23)C1=O</smiles>

TMC-120 B

Figure 4. Structures of aspergillitine and alkaloid TMS-120 B from Aspergillus versicolor

The synthesis of aspergillitine was achieved by Simonetti et al. in 11 steps and in $15 \%$ overall yield from 2,4dihydroxypropiophenone, through the intermediacy of 2,3-dimethyl-7-hydroxy-8- 
formylchromone 49 [87]. Triflation of 7hydroxy-8-formylchromone

49 and subsequent acetalization of the compound $\mathbf{7 8}$ set the stage for Stille allylation to the product 79. Construction of the nitrogen-bearing heterocyclic ring involved a Stille crosscoupling reaction with $n-\mathrm{Bu}_{3} \mathrm{SnCH}_{2} \mathrm{CH}=\mathrm{CH}_{2}$, followed by double bond isomerization to derivative 80, oximation of the chromone carbonyl (81), and a final microwave-assisted electrocyclization of the thus formed $6 \pi$ electron aza-triene system [87] (Scheme 26).<smiles>Cc1oc2c(C=O)c(O)ccc2c(=O)c1C</smiles><smiles></smiles><smiles>COc1oc2c(C)c(OS(=O)(=O)C(F)(F)F)ccc2c(=O)c1C</smiles><smiles>C=CCc1ccc2c(=O)c(C)c(C)oc2c1C=O</smiles>

78

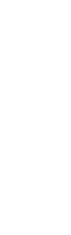


was synthesized from the corresponding phenyliodonium salt $\mathbf{8 4}$, which was obtained from the ester $\mathbf{7 8}$ according to the Scheme $\mathbf{2 7}$ $[89,90]$.
The ${ }^{18}$ F-labeled analog of $\mathbf{8 3}$ was synthesized analogously using $\left[{ }^{18} \mathrm{~F}\right]-$ tetrabutylammonium fluoride at the final stage $[89,90]$.

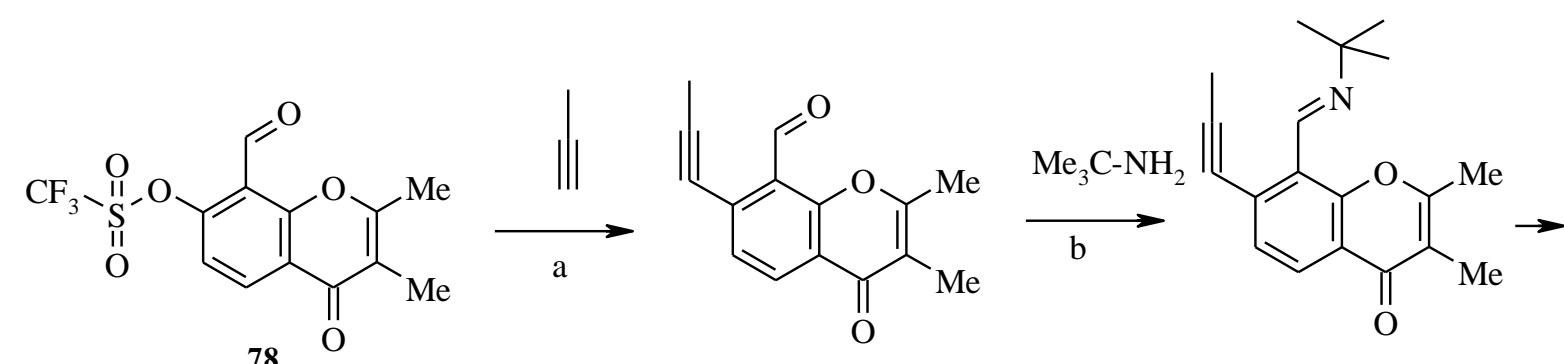<smiles></smiles>

a: triphenylphosphine-palladium(II) chloride, copper(l) iodide, triethylamine in N,N-dimethyl-formamide,

Time $=12 \mathrm{~h}, \mathrm{~T}=70^{\circ} \mathrm{C}$, Inert atmosphere

b: $20^{\circ} \mathrm{C} / \mid$ Molecular sieve

c: 1 . silver nitrate / N,N-dimethyl acetamide $/ 0.33 \mathrm{~h} / 20^{\circ} \mathrm{C}$

$2.3 \mathrm{~h} / 20^{\circ} \mathrm{C}$

d: potassium fluoride; 18 -crown-6 ether / N,N-dimethyl-formamide / $0.67 \mathrm{~h} / 100^{\circ} \mathrm{C} /$

Schlenk technique; Autoclave; Inert atmosphere

Scheme 27. The synthesis of 7-fluoro-2,3,4-trimethyl-4H-pyrano[3,2-h]isoquinolin-4-one $\mathbf{8 3}$

\section{Conclusions}

In conclusion, the evidence from the literature data suggests that the wide spectrum of biological activities of naturally occurring heterocyclic ring fused chromones has stimulated interest in the development of synthesis methods of compounds, containing such skeletons. It is rather important to choose an appropriate starting material, which enables obtaining a wide range of required products. 8-Carbonyl-7-hydroxychromones proved to be versatile synthones for the synthesis of chromones fused with heterocycles at $\mathrm{C}(7)$ $\mathrm{C}(8)$ bond, whereas the availability of the carbonyl group ortho to the hydroxyl group in the chromone cycle enables annulation reactions. The present review represented the advances in the synthesis of chromones annulated with $O$ containing 5- and 6-membered heterocycles, such as furan, pyrane, $\alpha$ - and $\gamma$-pyrone and their more complicated derivatives, as well as their $N$ - 
containing 5-7-membered analogues, such as oxazole, pyrazole, pyridine and diazepine rings based on the 7-hydroxy-8formyl/acetyl/benzoylchromones. The biological activity of angular hetarenochromones has been

\section{References}

[1] Gaspar A, Matos MJ, Garribo J, Uriarte E, Borges F. Cromone: A Valid Scaffold in Medicinal Chemistry. Chem. Rev. 2014; 114(9): 49604992.

[2] Keri RS, Budagumpi S, Pai RK, Balakrishna RG. Chromones as a privileged scaffold in drug discovery: A review. Eur. J. Med. Chem. 2014; 78: 340-374.

[3] Lozinskii OA, Shokol TV, Khilya VP. Synthesis and biological activity of chromones annelated at the $\mathrm{C}(7)-\mathrm{C}(8)$ bond with heterocycles . Chem. Heterocycl. Comp. 2011; 47(9): 1055-1077.

[4] Yadav PP, Gupta P, Chaturvedi AK, Shukla PK, Maurya R. Synthesis of 4-hydroxy-1methylindole and benzo[b]thiophen-4-ol based unnatural flavonoids as new class of antimicrobial agents. Bioorg. Med. Chem. 2005; 13(5): 1497-1505.

[5] Rangaswami S, Seshadri TR. 7Hydroxychromone-8-aldehydes and their conversion into chromono-7:8- $\alpha$-pyrones. Proceedings Indian Acad. Sci., Sect. A. 1939; 9(1): 7-9.

[6] Jayaprakash Rao Y, Thirupathi G, Prasad Rao Ch, Hemasri Y. Synthesis of novel substituted pyrano annulated flavones. Russ. J. General Chem. 2016; 86(5): 1126-1131.

[7] Chung S-T, Huang Y-T, Hsiung H-Y, Huang W-H, Yao C-W, Lee A-R. Novel daidzein analogs and their in vitro anti-influenza activities. Chemistry and Biodiversity. 2015; 12(4): 685-696.

[8] Shokol TV, Turov VA, Semenyuchenko VV, Khilya VP. Azaheterocyclic derivatives of $\alpha$-pyrono[2,3-f]isoflavones. Chem. Nat. Comp. 2006; 42(6): 668-672. also mentioned. There is much scope in the reported synthetic strategies and it is anticipated that the observed approach would give rise to design of molecules with enhanced biological properties.

[9] Shokol TV, Lozinskii OA, Tkachuk TM, Khilya VP. 7-Hydroxy-3-phenoxy-8formylchromones, analogs of natural flavonoids. Chem. Nat. Comp. 2009; 45(3): 350-355.

[10] Shokol TV, Lozinskii OA, Turov AV, Khilya VP. Synthesis of 9-azolyl-3-(4phenyl-4H-1,2,4-triazol-3-yl)-4H,8H-pyrano-[2,3f]chromene-4,8-diones. Chem.Het. Comp. 2009; 45(9): 1089-1094.

[11] Shokol TV, Lozinskii OA, Tkachuk TM, Volovnenko TA, Khilya VP. Furyl analogs of $\alpha$ pyrono[2,3-f] isoflavones with an azole substituent in the $\alpha$-pyrone nucleus. Chem.Het. Comp. 2010; 46(6): 675-680.

[12] Mannkind corporation. Zeng Q, Toro A, Patterson J, Bruce W, Warren S, Zubovics Z, YANG Y, Wu Z. Ire - $1 \alpha$ inhibitor. Japan patent 2015/214548. 2015 March 12.

[13] Da Re P, Setnicar V. Mannich reaction on 7-hydroxychromones and flavones. Synthesis of powerful central nervous system stimulants. J. Org. Chem. 1960; 25(7): 1097-1100.

[14] Shokol TV, Gorbulenko NV, Tkachuk TM, Khilya VP. Convenient method for synthesis of 3-(het)aryl-8-formyl-7-hydroxychromones. Chem. Het. Comp. 2009; 45(3): 370-371.

[15] Wittig G. Darstellung von benzo-di$\gamma$-pyronen. Chem. Ber.1926; 59(1): 116-119.

[16] Kelkar GR, Limaye DB. Influence of an acyl group in the 3-position on reactions of chromones. II. Action of aluminum chloride on 7 benzoyloxy-2-methyl-3-acetylchromone. Rasayanam. 1939; 1: 183-186.

[17] Parich SM, Thakor VM. Fries transformation and Friedel-Crafts reaction. Part III. 
Friedel-Crafts acylation of some hydroxychromones. J. Indian Chem. Soc. 1959; 36: 841-842.

[18] Alam M.S, Lee D.-U. Cytotoxic and antimicrobial properties of furoflavones and furochalcones. J. Korean Soc. Appl. Biol. Chem. 2011; 54(5): 725-730.

[19] Michaelis M, Rothweiler F, Nerreter T, Sharifi M, Ghafourian T, Cinatl J. Karanjin interferes with $\mathrm{ABCB} 1, \mathrm{ABCC} 1$, and $\mathrm{ABCG} 2 . \mathrm{J}$. Pharm. Pharm. Sci. 2014; 17(1): 92-105.

[20] Bheemasankara Rao Ch,

Subramamyam G, Venkateswariu V. Synthesis of Chromones. III. Furano and pyrono derivatives of chromone. J. Org. Chem. 1959; 24: 685-687.

[21] Kelkar GR, Limaye DB. Syntheses in the furochromone group. I. Furochromones from hydroxychromones. Rasayanam. 1941; 1: 228-230.

[22] Ramachandra Row L, Seshadri TR. Synthetic experiments in the benzo-pyrone series. Part XVII. Some isoflavono-7:8-furans. Proceedings Indian Acad. Sci., Sect. A. 1951; 34: 187-196.

[23] Ramachandra Row L, Seshadri TR. Synthetic experiments in the benzopyrone series. Part XV. Synthesis of karanjin. Proceedings Indian Acad. Sci., Sect. A. 1951; 33: 168-172.

[24] Aneja R, Mukerjee SK, Seshadri TR. Synthesis of benzo-furan derivatives-I. Karanj ketone, karanjin and pongapin. Tetrahedron. 1958; 2: 203-210.

[25] Rangaswami S, Seshadri TR. Synthetic experiments in the benzo-pyrone series. Part I Synthesis of karanjin- $\alpha$-carboxylic acid. Proceedings Indian Acad. Sci., Sect. A. 1939; 9(3): 259-264.

[26] Rodighiero P, Pastorini G, Chilin A, Manzini P, Guiotto A. Synthesis of some methylfurochromones as potential photochemotherapeutic agents. J. Heterocycl. Chem. 1988; 25(2): 527-533.

[27] Satyanarayana Reddy S, Venkati M, Yayaprakash Rao Y, Sharma KK, Krupadanam GLD. A convenient synthesis of ethyl furo[2,3- h]flavone/chromone-8-carboxylates. Indian J. Chem. 2011, 50B: 1671-1676.

[28] Ramu M, Srinivasulu B. Facile synthesis of methyl-2-(furyl-2-yl) 3-methyl-4-oxo-4hfuro(2,3-H)chromene-8-carboxylate. Der Pharma Chemica 2015; 7(3): 226-229.

[29] Fukui K, Kawase Y. Synthetic studies on the benzofuran derivatives. Part V. Synthesis of furano(2',3':7,8)-isoflavone. Bull. Chem. Soc. Japan. 1958; 31(6): 693-695.

[30] Matsumoto T, Kawase Y, Nanbu M, Fukui K. Synthetic studies on the benzofuran derivatives. Part III. Reaction of 7-hydroxy-8-formyl2-methylisoflavone with ethyl bromomalonate and synthesis of furano(2',3':7,8)-2-methylisoflavone. Bull. Chem. Soc. Japan. 1958; 31(6): 688-690.

[31] Kawase Y, Matsumoto T, Fukui K. Synthetic studies on the benzofuran derivatives. Part 1 . A new synthesis of karanjin. Bull. Chem. Soc. Japan. 1955; 28(4): 273-280.

[32] Fukui K, Nakayama M, Okazaki K. Synthesis of furano[2', 3 '’:7,8]-3',4'methylenedioxyisoflavone. Nippon Kagaku Zasshi. 1964; 85(7): 446-449.

[33] Kawase Y, Ogawa K, Miyoshi S, Fukui K. Synthetic studies on the benzofuran derivatives. VI. Synthesis of furano(2', 3', :7,8)-2'methoxy-isoflavone derivatives. Bull. Chem. Soc. Japan. 1960; 33(9): 1240-1242.

[34] Fukui K, Nakayama M, Hatanaka M. The synthesis of elliptol isoflavone. Bull. Chem. Soc. Japan. 1963; 36(7): 872-873.

[35] Sharada J, Kanakalingeswara Rao M. Synthesis of 8-Aroyl-9-phenylfuro<2,3-h>-1benzopyran-4(H)-ones as Possible Antiimplantation Agents. Indian J. Chem., Sect. B. 1985; 24: 1091-1093.

[36] Sharada J, Krishna Murthy KS, Rajitha B, Kanakalingeswara Rao, M. Synthesis of aroyl benzopyrones as possible anti-implantation agents. Indian J. Heterocycl. Chem. 1999; 9(7): 7-12. 
[37] Satyanarayana Reddy S, David Krupadanam GL. Facile synthesis of 9acetyl/formyl/cyano-substituted pyrano[2,3-f]flavones and chromones using the Baylis-Hillman reaction. Synth. Commun. 2010; 40(9): 1292 - 1304.

[38] Jayaprakash Rao Y.; Niranjan K; Hemasri Y, David, Krupadanam G.L. Synthesis of novel-9-cyano/acetylpyrano[2,3-f]chromones via Baylis-Hillman reaction. Heterocyclic Commun. 2011; 17 (5-6): 173-176.

[39] Chenna Krishna Reddy R, Madhusudana Rao G, Thirupal Reddy M, Rami Reddy YV. Facile synthesis of 9-acetyl-pyrano[2,3f]isoflavones. Asian J. Chem. 2013; 25(9): 4833-4835.

[40] Venkata Suryanarayana Ch, Anuradha V. An efficient synthesis of heteroannulated chromene-9-carbonitrile derivatives via Baylis-Hillman reaction. International J. Curr. Pharm. Res. 2013; 5(3): 36-39.

[41] Jayaprakash Rao Y, Thirupathi G, Prasad Rao Ch, Hemasri Y. Synthesis of novel substituted pyrano annulated flavones. Russ. J. General Chem. 2016;. 86(5): 1126 - 1131.

[42] Ramachandra Row L, Seshadri TR. Flavylium salts containing pyrone rings. Proceedings Indian Acad. Sci., Sect. A. 1942; 15: 118-122.

[43] Pastorini G, Rodighiero P, Manzini P, Conconi MT, Chilin A, Guiotto A Methylpyranochromones and methylbenzodipyranones: new potential photoreagents towards DNA Gazz. Chim. Ital. 1989; 119(9): 481-485.

[44] Vijava Lakshmi M, Subba Rao NV. Synthesis and bacteriostatic activity of linear $(7,6)$ and angular (7,8)- $\alpha$-pyronochromones. Curr. Sci. 1973; 42(1): 19-21.

[45] Thakar KA, Manjaramkar NR. Synthesis of 2-heterocyclic substituted coumarino- $\gamma$ pyrones. Indian J. Chem. 1971; 9: 892-893.
[46] Joshi BS, Kamat VN. Structures of clausenin and clausenidin and syntheses of clausenin and xanthoxyletin. Tetr. Lett. 1966; 46: 5767-5773.

[47] Joshi BS, Kamat VN, Saksena AK Structure of clausenin and clausenidin, two new pyranocoumarines from the roots of Clausena heptaphylla. Tetrahedron. 1967; 23(12): 4785-4789.

[48] Asai F, Iinuma M, Tanaka T, .Mizuno M. Two complex flavonoids in the farinose exudate of Pityrogramma Calomelanos. Heterocycles. $1992 ; 33(1)$ : 229-233.

[49] Iinuma M, Tanaka T, Asai F. Flavonoids in frond exudates of Pityrogramma tartarea. Phytochemistry. 1994; 36(4): 941-941.

[50] Kawase Y, Sekiba T, Fukui K. Synthesis of isoflavono( $\left(7^{\prime}, 8^{\prime}: 6,5\right)$ - $\alpha$-pyrones and formylation of 2,4-dihydroxyphenyl benzyl ketone. Bull. Chem. Soc. Japan. 1958; 31(8): 997-998.

[51] Lozinski OA, Shokol TV, Shishkin OV, Medvediev VV, Khilya VP. The redeeming features of reaction of the 8-formyl-7hydroxychromones with malononitrile. Fr.Ukr. J. .Chem. 2014; 2(1): 10-15.

[52] Shokol TV, Gorbulenko NV, Khilya VP. 9-Azahetaryl-3-(isoxazol-3-yl)pyrano[2,3f]chromen-4,8-diones. Dopov. NAS Ukraine. 2010; (7): 142-145.

[53] Lozinski OA, Shokol TV, Khilya VP. 4H,8H-Pyrano[2,3-f]chromene-4,8-diones as versatile precursors for the 6-(1,2-oxazole-5-yl)-2H-chromene2-ones synthesis. Monatsh. Chem. 2013; 144(2): 217222

[54] Shokol TV, Nestorak IYu, Turov AV, GunkoVM, Volovenko YuV, Khilya VP. 3-[2(4)Pyrimidinyl]coumarins and their condensed analogs. Chem. Het. Comp. 2010; 46(7): 829-838.

[55] Rao HSP, Tangeti VS. Synthesis of 3-aroylcoumarin-flavone hybrids. Lett Org. Chem. 2012; 9(3): 218-220. 
[56] Kaneta M, Sugiyama N. The structure of a new flavone, "arthraxin". Bull. Chem. Soc. Japan. 1969; 42(7): 2084.

[57] Kaneta M, Sugiyama N. The structure of a new flavone, 'Arthraxin'. J. Chem. Soc. (C). 1971; (10): 1982-1986.

[58] Kaneta M, Sugiyama N. The constituents of Arthraxon hispidus Makino, Miscanthus tinctorius Hackel, Miscanthus sinensis Anderss and Phragmites communis Trinius. Bull. Chem. Soc. Japan 1972; 45(2): 528-531.

[59] Sugiyama N, Kaneta M. Extracting yellow dye from Arthraxon hispidus Makino. Japan patent 7300164. 1973 Jan. 06.

[60] Kaneta M, Sugiyama N. The light resistance of complex salts of flavones and flavonols. Bull. Chem. Soc. Japan 1973; 46(7): 2265-2266.

[61] Kaneta M, Hikichi H, Endo S, Sugiyama N. The synthesis of new flavones with a 4H,10H-benzo[1.2-b:3,4-b']dipyran-4,10-dione skeleton and light resistance of these compounds. Bull. Chem. Soc. Japan 1978; 51(6): 1784-1787.

[62] Murthy YLN, Srinivas ASSV. Synthesis of new flavanoid derivatives as liquid crystals. Indian. J. Het. Chem. 1991; 1(2): 91-94.

[63] Bantick JR, Cairns H, Chambers A, Hazard R, King J, Lee TB, Minshull R. Benzodipyran derivatives with antiallergic activity. J. Med. Chem. 1976; 19(60): 817-821.

[64] Kumar KA, Srimannarayana G. Analogs of disodium cromoglycate as antiallergic agents: part I - synthesis of some chromone carboxylic acids: 4,10-dioxo-2-phenyl-4H,10H-benzo[1,2-b:3,4b]dipyran-8-carboxylic acids. Indian. J. Chem., Sect. B. 1984; 23(10): 969-972.

[65] Cairns H, Minshull R. Antiasthmatic benzopyrones. S. Africa patent (ZA) 6804981. 1969. Mar. 24.

[66] Cairns H, Roders NH. Benzopyranund thiabenzopyran- verbindungen, verfahren zu deren herstellung und diese enthaltende pharmazeutische praparate. German patent (DE) 2247969. 1973.Apr.5.

[67] Cairns H, Minshull R. Substituted benzodipyrones. Britain patent (GB) 1230087. 1971.Apr.28.

[68] Cairns H, Minshull R. Benzodipyrones. United States patent (US) 3718668. 1973 Feb 27.

[69] Cairns H, Johnson PB, Minshull R. Neue verbindungen. German patent (DE) 2235572. 1973 Feb 8.

[70] Wittig G. Zur Erschließung der Benzo- $\gamma$-pyrone. Ann. Chem.1926; 446(1): 155-204.

[71] Omote Y, Takizawa Y, Sugiyama N. The synthesis of 2,8-diphenyl-4H,10H-benzodipyran4,10-dione. Bull. Chem. Soc. Japan 1971; 44(4): 1160.

[72] Lozinski O, Shokol T, Khilya V. A novel method of synthesis of the $4 H, 10 H$-pyrano[2,3f]chromen-4,10-dione system. Bull. Taras Shevchenko National University of Kyiv. 2015; 1(51): 61-63.

[73] Schlitter E, Spitaler U. On the contents of Schumanniophyton problematicum (Rubiaceae). Tetr. Lett. 1978; 19(32): 2911-2914.

[74] Houghton PJ, Hairong Y. Novel chromone alkaloids from Schumanniophyton magnificum. Planta Medica. 1985; (1): 23-27.

[75] Houghton PJ, Hairong Y. Further chromone alkaloids from Schumanniophyton magnificum. Planta Medica. 1987; 53(3): 262-264.

[76] Houghton PJ, Woldemariam TZ, Khan AI, Burke A, Mahmood N. Antiviral activity of natural and semi-synthetic chromone alkaloids. Antiviral Res. 1994; 25(3-4): 235-244.

[77] Jayaprakash Rao Y, David Krupadanam GL. A facile synthesis of 7,8/6,7 fused pyrano[4,3-b]pyridinochromones and evaluation of antibacterial activity. Indian J. Chem 2000; 39B: 610630 .

[78] Soni AK, David Krupadanam GL, Srimannarayana G. Facile synthesis of 7-methoxy-2- 
aryl-3-phenyl/or-H-8-[2-(4,6-dimethyl-3,5-

dicarbethoxy-pyridyl)]-4H-1-benzopyran-4-ones.

Synth. Commun. 2007; 37(5): 795-804.

[79] Naveen Kumar B, Venkatesham A, Nagaiah K, Jagadeesh Babu N. Synthesis of new pyrano[2',3':5,6]chromeno[4,3-b]quinolin-4-ones via aza-Diels-Alder reaction. Helv. Chim. Acta. 2015; 98(3): 417-426.

[80] Venkatesham A, .Srinivasa Rao R, Nagaiah K, Yadav JS, RoopaJones G, Basha SJ, Sridhar B, Addlagatta A. Synthesis of new chromenoannulated cis-fused pyrano[3,4-c]pyran derivatives via domino Knoevenagel-hetero-Diels-Alder reactions and their biological evaluation towards antiproliferative activity. Med. Chem. Comm. 2012; 3(6): 652-658.

[81] Nagaiah K, Venkatesham A, Srinivasa Rao R, Saddanapu V, Yadav JS, Basha SJ, Sarma AVS, Sridhar B, Addlagatta A. Synthesis of new cis-fused tetrahydrochromeno[4,3-b]quinolines and their antiproliferative activity studies against MDA-MB-231 and MCF-7 breast cancer cell lines. Bioorg. Med. Chem. Lett. 2010; 20(11): 3259-3264.

[82] Naveen Kumar B, Venkatesham A, Madda J, Kommu N, Sujitha P, Ganesh Kumar C, Rajendra Prasad K, Jagadeesh Babu N. Synthesis of new chromeno-annulated cis-fused pyrano[4,3c]isoxazole derivatives via intramolecular nitrone cycloaddition and their cytotoxicity evaluation. Bioorg. Med. Chem. Lett. 2013; 23(14): 4061-4066.

[83] Madda J, Venkatesham A; Naveen Kumar B, Nagaiah K, Sujitha P, Ganesh Kumar C, Rao TP, Jagadeesh Babu N. Synthesis of novel chromenoannulated cis-fused pyrano[3,4-c]benzopyran and naphtho pyran derivatives via domino aldol-type/hetero Diels-Alder reaction and their cytotoxicity evaluation Bioorg. Med. Chem. Lett. 2014; 24(18): 4428-4434.

[84] Subhadra Kumari S, Krishna Mohan Rao KSR, Subba Rao NV. Isoxazolo(7,8-d)flavones. Proc. Indian. Acad. Sci. 1973; 77: 149-156.
[85] Culshaw AJ, Brain CT, Dziadulewicz EK, Edwards L, Hart TW, Ritchie TJ, inventors; Novartis Ag., assignee. Chromone derivatives useful as antagonists of vr1 receptors. World Intellectual Property Organization (WO) patent 2007065888. 2007 Jun 14.

[86] Lin W, Brauers G, Ebel R, Wray V, Berg A, Proksch P. Novel chromone derivatives from the fungus Aspergillus versicolor isolated from the marine sponge Xestospongia exigua. J. Nat. Prod. 2003; 66(1): 57-61.

[87] Simonetti SO, Larghi EL, Bracca ABJ, Kaufman TS. Synthesis of the unique angular tricyclic chromone structure proposed for aspergillitine, and its relationship with alkaloid TMC120B. Org. \& Biomolecular Chem. 2012; 10(20): 4124-4134.

[88] Simonetti SO, Larghi EL, Bracca ABJ, Kaufman TS. Angular tricyclic benzofurans and related natural products of fungal origin. Isolation, biological activity and synthesis. Nat. Prod. Rep. 2013; 30: 941-969.

[89] Yuan Z, Cheng R, Chen P, Liu G, Liang SH. Efficient pathway for the preparation of aryl(isoquinoline)iodonium(III) salts and synthesis of radiofluorinated isoquinolines. Angew. Chem. - Int. Ed. 2016; 55(39): $11882-11886$.

[90] Yuan Z, Cheng R, Chen P, Liu G, Liang SH. Efficient pathway for the preparation of aryl(isoquinoline)iodonium(III) salts and synthesis of radiofluorinated isoquinolines. Angew. Chem. 2016; 128(39): 12061 - 12065. 